\title{
Emmanuel Levinas in predsokratiki
}

\section{Tanja Rebula* in Edvard Kovač**}

Levinas se kljub številnim antičnim mitološkim in širšim literarnim reminiscencam in kljub svoji zakoreninjenosti v judovskem duhovnem izročilu vedno znova vrača k izražanju, ki bi lahko doseglo vsakega človeka in ki bi bilo torej v tem smislu univerzalno, ker bi ga bilo mogoče izraziti z razumsko opredeljivimi pojmi. To pa ne pomeni, da bi želel omejiti filozofijo na golo formo logičnih kategorij in jo prikrajšati za njeno pravico do legitimnih vprašanj, ki od samih izvorov dalje ostajajo srčika filozofije v njenem etimološkem pomenu ljubezni do modrosti, ki je veliko več kot samo razum. Ali še bolje - Levinas bo širil polje razuma z novo pojmovnostjo, vendar njegova modrost ostaja še vedno razumna. V kakšnem smislu pa gre pri Levinasu za »drugačno razumnost«, je mogoče odkrivati le postopoma, skozi plasti njegovega "palimpsesta«. V naslednjih besedah se že nakazuje smer Levinasovega utiranja novih poti:

Drugačna - ali globlja - razumnost, ki se ne pusti ujeti v dogodivščino, kakršna je potekala od Aristotela do Heideggerja: teologija, ki je ostala misel Identitete in Biti in ki je bila pogubna za Boga ter za bibličnega človeka ali njegove homonime. (DQVI 168:2) ${ }^{1}$

Pravo vprašanje je, ali Levinas to univerzalnost razuma, ki jo bo razširil preko etike kot prve filozofije, zasluti že pri začetkih grške filozofije. Odgovor je treba iskati v sledovih antike v njegovem delu; tu

* Državni znanstveni licej Franceta Prešerna, Vrdelska cesta 13/1, 34128 Trst, tanreb@libero.it.

** Teološka fakulteta Univerze v Ljubljani, Poljanska cesta 4, 1000 Ljubljana, edvard.kovac@guest.arnes.si.

1 Prevodi so vzeti iz obstoječih izdaj Levinasovih del (v bibliografiji); kjer jih še ni, so delo avtorjev. 
je najprej Levinasov odnos do grštva, potem iskanje izvora (å $\rho \chi \eta ́),{ }^{2}$ nato pa odnos do posameznih predsokratikov - do Talesa, Anaksimandra, Anaksimena, Heraklita in Parmenida.

\section{LEVINASOV ODNOS DO GRŠTVA}

Mi, zahodnjaki, se od Kalifornije do Urala hranimo z Biblijo vsaj toliko kot s predsokratiki. (HAH 96)

Ta Levinasova izjava je umeščena v poglavje o tujosti, ${ }^{3}$ ki jo človek doživlja $v$ svetu in ki preveva tudi psalmista $\mathrm{v}$ psalmu 119 (Levinas ga omenja v istem kontekstu). ${ }^{4}$ Biti tujec na zemlji je prastaro občutje. Levinas, sodobni mislec, se kritično sprašuje ob besedah, ki jih Heidegger nameni vlogi človeka v odnosu do biti: »Ali je človek res le pastir biti ali pa gre za osebno izvoljenost? « ${ }^{5}$ In kako Levinas pojmuje »izvoljenost«? O tem govori naslednji odlomek:

Seveda se v filozofiji ne poslužujem samo klasičnih kategorij od Aristotela do Kanta in Hegla. Toda pojem, kot je izvoljenost, ni niti ljudski niti čaroben. Izvoljenost zame nadomešča pojem individuacije. (TEI 43:24)

Po Levinasu je človek več kot Heideggerjev "pastir biti«, edina možnost srečanja s transcendenco je obličje sočloveka, ki mu predstavlja klic k neskončno odgovornemu etičnemu od-govoru. Gre torej za osebno poklicanost in odgovornost, ki se dogaja v odnosu. ${ }^{7}$ Za Levinasa je to osrednje vprašanje, ki pa je neločljivo povezano $\mathrm{z}$ vsemi ostalimi vprašanji, z začetki filozofije v antični Grčiji.

Vloga grškega jezika in kulture je za Levinasa temeljnega pomena, saj izraža miselno disciplino, zaobseženo v izrazu $\lambda o ́ \gamma o \varsigma$, obenem pa svet vrednot $v$ najširšem smislu besede.

2 Narbonne, Levinas et l'héritage grec, 34.

3 Levinas, Humanisme de l'autre homme, 96-97.

4 Ps 119,19: »Jaz sem tujec na zemlji, ne skrivaj pred menoj svojih zapovedi.»

5 HAH, 96.

6 Klun, Das Gute vor dem Sein.

7 Klun, »L'infini et la passivité«, 23-43. Levinasov odnos do Heideggerja je sicer kompleksno vprašanje, ki ga na tem mestu ni mogoče podrobneje razdelati; prim. npr. Françoise Dastur, »Levinas and Heidegger: Ethics or Onthology?« V: Between Levinas and Heidegger, ur. John E. Drabinski in Eric S. Nelson, 133-158, pa tudi druga poglavja $\mathrm{v}$ tem zborniku. 
Kljub koncu evrocentričnosti, ki so jo razvrednotile tolike grozote, verjamem v vzvišenost človeškega obličja, ki ga izraža grška književnost, pa tudi naša, ki grški dolguje vse. (EI 126:9)

Vračanje k predsokratikom je najprej vračanje k vprašanjem o izvoru, ki se nanašajo na prvinsko povezanost $\mathrm{z}$ naravo, s slutnjo neke nevidne veličine v njej. Kaj pravzaprav predstavljajo jonski naravoslovci? Čas, ki mu je razlikovanje med neživo snovjo in življenjskim oziroma gibalnim principom, principom nastajanja, preminevanja in spreminjanja, tuje. Raziskovalci danes ugotavljajo, da so to razlikovanje vzpostavili šele poznejši filozofi, deloma Empedokles, Anaksagora in zlasti Aristotel. Talesu pripisujejo izrek »vse je polno bogov« (A 22), Anaksimander in Anaksimen sta menila, da ima ả $\rho \eta ́$ božanske lastnosti. Pomem-

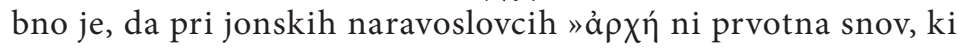
bi jo preoblikovale druge sile; enotna resničnost ni sestavljena iz materije in življenjskega principa, temveč je v celoti in v vsakem svojem delu živa. Ta pogled na svet ni bil lasten samo jonskim naravoslovcem, temveč Grkom tega časa nasploh. « ${ }^{8}$

Ti prvi uvidi se nanašajo na prvine, kot sta na primer voda ali zrak, a predstavljajo obenem iskanje globljih razsežnosti, iskanje praizvora, slutnjo božanskega v pojavnem svetu. V grškem mitu so naravne sile nastopale $\mathrm{v}$ antropomorfni obliki in $\mathrm{v}$ kontekstu politeizma. Začetke filozofije pa zaznamuje ravno ta odmik od predstav, ki so sicer del grškega izročila, a se pri jonskih naravoslovcih $^{9}$ izoblikujejo v prve filozofske predstave in pojme.

Od Talesa do Parmenida ali atomista Demokrita je očitna slutnja grških »ljubiteljev modrosti«, da je pojavnost sveta le videz, del širše in drugačne resničnosti, ki pa našim čutom ni povsem dostopna. Gre za iskanje božanskega, v pomenu tistega, k čemur teži in je usmerjena vsa narava in človek $\mathrm{z}$ njo, obenem pa je to spraševanje povezano s temeljnim vprašanjem o smislu človeka, o njegovi preteklosti in prihodnosti.

Čeprav je šele Platon uvedel pojem »teologija«, kot opozarja Jean Marc Narbonne v svojem temeljitem prikazu Levinas et l'héritage grec, ${ }^{10}$ so že sami začetki filozofije v Grčiji pokazali,

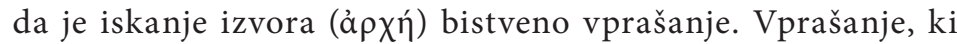
pomeni začetek filozofije, obenem pa je neločljivo prepleteno $\mathrm{z}$ vprašanjem transcendence. Če nam pojem teologija v širšem

8 Marinčič, Grška književnost arhaične dobe, 163-64.

9 Ibid., 165-69.

10 Narbonne, Levinas et l'héritage grec, 35. 
smislu pomeni obravnavanje vsega, kar se nanaša na Boga $\mathrm{v}$ najširšem smislu besede, je notranja povezanost med filozofijo in teologijo po Narbonnu conditio sine qua non predsokratskih filozofov in z njimi nadaljnje filozofske poti, ne glede na to, $\mathrm{v}$ kateri smeri si je vsak izmed poznejših filozofov odgovarjal na ta vprašanja.

\section{TALES}

Ko se Levinas ${ }^{11}$ vrača $\mathrm{k}$ jonskim naravoslovcem, jih omenja $\mathrm{v}$ povsem novem kontekstu, večkrat splošnem in mestoma fragmentarnem. Razvidno pa je, da je zanj pomembno izhodišče, kakršnega so imeli kljub različnosti vsi predsokratiki. Ob vprašanjih naravoslovja, katerega metode veljajo še danes za prototip znanstvenega raziskovanja (empirično eksperimentalnega), so tvegali "potopitev v skrivnost«, v odkrivanje vsega tistega, česar ni mogoče zaobseči z istimi metodami, ki so dostopne tem znanostim. A ravno to tveganje poraja filozofijo.

Tales je pri Levinasu včasih omenjen le kot mejnik, ki pomeni začetek filozofske misli »od Talesa do Hegla«. Omenja pa ga tudi v nekoliko širšem kontekstu, v katerem se zdi, kot da bi bilo danes izreči misel, da je vse voda, neko arhetipsko mišljenje.

Ampak kako naj strukturi resničnosti - kakršno je odkrila evropska filozofija »od jonskih otokov pa do filozofa v Jeni« - z enako pravico do resnice postavimo nasproti ontologijo verske resnice, novo misel, ki je enako suverena kot filozofija od Talesa do Hegla? Prav to je namen knjige Zvezda odrešenja. Talesova trditev »vse je voda« je za Rosenzweiga prototip filozofske resnice. (DL 243:21)

Zdi se, da se Levinasu postavljajo vprašanja, ki so se že davno prej odpirala predsokratikom. Težava je v tem, da so že prvi zbiratelji fragmentov vse od Teofrasta dalje vnašali svoje interpretacije, ki še vedno nastajajo. A morda je bil in ostaja ravno to njihov trajni in vedno nov izziv. Toda današnji čas ne dopušča več te predanosti

11 Levinas omenja Talesa v DMT 85:11; DL 243:25, 243:27; HS 81:6, 81:8, 82:4, 101:10; skupno torej sedem omemb. 
prapočelu, ${ }^{12}$ čeprav je misel skozi dolga stoletja zorela zato, da lahko znova odkriva svoje meje in nove možnosti. Po Levinasu je namreč davna preteklost zapisana $\mathrm{v}$ genom človeške vrste, čeprav ga sam ne imenuje tako. To pra-zaznamovanost človeka s prapočelom imenuje drugače. Iz pradavnine, ki nikoli ne bo doumljiva, po Levinasu namreč izhaja tudi nekaj, kar ni snov, ni voda. To je zapisanost transcendenci na obličju sočloveka. Levinasova filozofska pot torej izhaja iz daljne preteklosti, tiste, ki je bila, preden je bila misel, preden je ta spregovorila - iz predsokratikov. Obenem pa se sam nenehno vrača tudi v neko drugo preteklost, ki se ne nanaša na naravo, ampak na človeka samega.

V Levinasovem delu Dieu, la Mort et le Temps (Dмт) sta objavljena dva sklopa njegovih predavanj na Sorboni v akademskem letu 1975/76. V prvem delu, Smrt in čas, najdemo eno izmed pomenljivih omemb Talesa:

Tako se takoj znajdemo v položaju, podobnem tistemu, ki ga je mislil Aristotel: obstaja neki nič, vendar ta nič pričakuje bit, nič, ki hoče bit, ki je na tem, da bo prešel v bit. Lahko se torej vprašamo, ali na tak način ne predpostavljamo, da so bitja že tam. Če tako začetek ni začetek nečesa, začetek tega, kar se začenja. Začetek, ki nima določenosti vode kot pri Talesu, a ki ima zgradbo nečesa. (DMT 85:18)

To vprašanje, kako in kdaj se poraja to, kar ni nekaj določenega, ki pa niti ni nič, nas povezuje z izvornim iskanjem počela.

$\mathrm{V}$ Levinasovem izboru različnih razprav, ki je izšel pod naslovom Hors sujet ${ }^{13}$ srečamo Talesa $\mathrm{v}$ krajšem razmišljanju $\mathrm{z}$ naslovom $» \mathrm{Ka}$ tegorije nove misli«, kjer izhaja predvsem iz Rosenzweiga. Tudi tu predstavlja Tales najprej mejnik zahodne filozofije, ki se razteza »od Talesa do Hegla«. Očiten pa je Levinasov kritični pristop do vsega v zgodovini filozofije, kar bi poskušalo zvesti vso pestrost resničnosti,

V sklepnem delu uvodne študije k Fragmentom Gorazd Kocijančič ugotavlja, da ostaja odprto vprašanje pristnosti fragmentov in vseh poznejših kontekstov in razlag. A problem ni le vnašanje aristotelskih ali novoplatonističnih razlag, gre za veliko globlje vprašanje. "Ne pomaga nam še tako celostno umeščanje misli $\mathrm{v}$ njen zgodovinski in literarni kontekst, [...] ker smo postavljeni v enak človeški položaj kot njihovi avtorji. Da smo smrtniki. [...] To, kar se daje v teh besedilih, [...] je duhovni okus Skrivnosti, vonj, uzrtje, v katerem se mešata realnost in beseda, zapisana nekoč. In verjetno je prav to namen tistih, ki so jih zapisovali.« Fragmenti predsokratikov, xxvi-xxvii.

13 Levinas, Hors sujet, 81. 
zlasti sočloveka, na skupni imenovalec, ki ne bi dopuščal enkratnosti posameznika. V tem primeru je iskanje nečesa, kar je na dnu isto, lahko omejevanje, zakrivanje ali celo nasilje nad drugostjo.

$\mathrm{V}$ tem pogledu je tudi Tales deležen Levinasove kritičnosti do splošne usmerjenosti zahodne filozofije. Ta po njegovem vodi v razumevanje resničnosti kot totalitete, ki v sebi použiva vso raznolikost. Predvsem pa človek ni samo predstavnik svoje vrste, ampak nezvedljiva individualnost. ${ }^{14} \mathrm{Ne}$ zadoščajo mu abstraktni etični principi in logični konstrukti, kajti mimo vseh zunanjih pravil je človek meta-etično bitje.

$\mathrm{V}$ naslednjem odlomku je razviden širši prikaz Levinasove kritičnosti tako do zahodne filozofije kot do antičnega pojmovanja sveta in človeka, prepuščenega slepi usodi:

Kako postaviti nasproti vrhovnim kategorijam filozofije, ki se je uveljavila »od jonskih otokov do Jene«, neko misel, ki naj bi presegala misleca? Katera je bila torej njena skrivnost od Talesa do Hegla? Odreči se izkustvu, da bi zmanjšali pestrost, ki se ponuja tistemu, kar naj bi bilo na dnu: reči »vse je voda« kot Tales. (Hs 81:6, 81:8)

Izstopiti iz totalitete pomeni Levinasu stopiti v meta-etični prostor, ${ }^{15}$ ki je arhaičen, ne vemo, od kod in od kdaj je, prav tako kot ne vemo za prapočelo. A v nas je, še preden se zavemo sebe. Rojeni smo za drugega, etična poklicanost je bila pred menoj, drugi me je poklical, da sem odkril sebe in svojo odgovornost. Antika ostaja v svojem temelju sicer iskanje praizvora biti, a ne preseže tragičnosti človeka, česar ne more preseči nobena filozofija. A tu gre spet za »stopanje v neznano" ali bolje v neko pra-preteklost, ki je poklicala človeka ne le k obstoju, ampak k človečnosti, to je k meta-etičnosti.

A čim človek odkrije, da je meta-etičen, in izstopi iz totalitete, se tudi Bog umakne iz totalitete in doseže svoje metafizično bistvo in svet, ki ga je idealizem zvedel na logični konstrukt, razkrije neizčrpno polnost svoje meta-logične biti. Potem ko so izstopila iz totalitete, v katero jih je združila filozofija od Talesa do Hegla, se ta bitja znajdejo ločena, ker so nezvedljiva; taka so se pokazala $\mathrm{v}$ izkušnji poganske antike: izoblikovani svet umetnosti, mitični Bog, ki živi v medprostorih biti, tragični človek sebstva, zaprtega vase, ki ga je zlomila slepa usoda. (Hs 82:4) 


\section{ANAKSIMANDER}

Iz fragmenta v Diels-Kranzu se zazdi, da denimo Avguštin v Anaksimandrovem pojmu ắcı pov ne vidi ničesar, kar bi lahko pomenilo razsežnost svetega ali božjega: »Kajti (Anaksimander) ne misli, da vse (stvari) nastanejo iz ene resničnosti, tako kot pri Talesu (nastanejo) iz vlage, ampak da se vse stvari porajajo iz svojih lastnih počel,« pravi cerkveni oče. »Verjel je, da so počela posameznih stvari brezmejna in da (iz njih) nastaja nešteto svetov ter vse, kar se rojeva $\mathrm{v}$ njih. O teh svetovih pa je menil, da enkrat propadajo in drugič spet nastajajo, kolikor dolgo pač vsak (izmed njih) lahko traja. Sam ni pri tem delovanju stvari ničesar pripisoval božanskemu umu. ${ }^{16}$

Levinas je očitno mislil drugače. Anaksimander je pri njem dele-

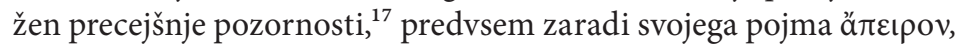
ki ga je mogoče razlagati na več načinov. Ker je pojem soroden poznejšim pojmom transcendence, neskončnosti in presežnosti nasploh, je ä́rııov izziv za vedno nove interpretacije. Levinas omenja Anaksimandra kot tistega, ki mu pripisuje »izstop « iz totalizacije, v katero je zabredla poznejša zahodna filozofija. Dve pomembni navedbi srečamo $\mathrm{v}$ Levinasovem delu $\mathrm{z}$ naslovom Altérité et transcendance (АT), ki obsega dvanajst krajših razprav, nastalih v obdobju od 1967 do 1989, torej po izidu njegovega temeljnega dela Totalité et infini (TI).

Kot pravi Pierre Hayat ${ }^{18} \mathrm{v}$ uvodni besedi, sta dve izmed njih nastali kot odgovor na pozive, da bi Levinas podrobneje in jasneje opredelil tako pojem neskončnosti kot pojem transcendence. To je v omenjenem delu Altérité et transcendance tudi storil. Ti dve razpravi - prva $\mathrm{z}$ naslovom »Philosophie et transcendance in druga $\mathrm{z}$ naslovom »Infini« - sta bili objavljeni tudi v Encyclopédie philosophique universelle. Tretja pomembna razprava $\mathrm{v}$ AT je »Totalité et totalisation«, prav tako objavljena v Encyclopédie. V tej najdemo sledečo Levinasovo trditev:

V teku zgodovine zahodne filozofije se je totalizacija sama izkazala kot nemogoča in se je lahko izrazila ob več priložnostih: $v$ dualizmu sil in nasprotujočih si vrednot pri Anaksimandru. (Ат 67:14) 


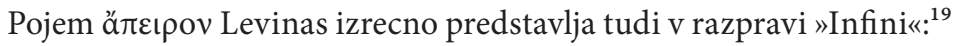

Za Anaksimandra (6. stol. pr. Kr.) je princip, ki ga imenuje äđદıрov, nenastali in neuničljivi izvor vseh stvari, ki jih vse vključuje in usmerja, ne da bi ga lahko zožili na katerokoli materialno prvino. "A $\pi \varepsilon \iota \rho \circ v$ je torej neizčrpna rodovitnost in poraja neskončno svetov. (AT 75:22)

Med »neskončno « odprtimi vprašanji o neskončnem omenja Levinas nekaj temeljnih izhodišč. Ali izhajamo iz končnosti in se tako bližamo neskončnosti, kar bi pomenilo, da gre za kvantitativno pojmovanje neskončnosti? Ali pa končnost izvajamo iz neskončnosti, ki je vedno nekje v ozadju vsega, kar je končno? Levinas omenja še veliko drugih pomenskih odtenkov, denimo idejo neskončnosti pri Descartesu, ki ni mogla nastati v končnem razumu, ampak je dokaz za presežno, ki je to idejo položilo v nas. Posebno vprašanje je, ali sam pojem neskončnosti vsebuje tudi atribute, ki veljajo za popolnost božjega, ali pa gre za povsem prostorsko in časovno razsežnost, ki ti dve »končni« kategoriji presega brez teološke konotacije.

Levinasov pogled na neskončnost tvori enega izmed dveh osrednjih pojmov dela Totalité et infini. Jedro njegovega sporočila je nedosegljivost neskončnega, ki ga je mogoče prepoznavati le na obličju sočloveka. Ta edina sled neskončnosti pa je klic k neskončni etični odgovornosti. Iz predstavitve fragmentov iz Anaksimandra in njihovih razlag je razvidno, da ắcı ki dopušča neomejene, neskončne možnosti porajanja in prerajanja, nastajanja in minevanja, a ostaja brezmejno kot neskončno ozadje vsega ustvarjenega. Vendar to ni Levinasov pojem, kajti sam ga ne povzema, pač pa se ob njem le navdihuje.

Izvirni Levinasov "pojem« pa je il y a. Tega opisuje že v svojem zgodnjem delu De l'Existence à l'Existant. ${ }^{20} \mathrm{~K}$ pojmu se vrača tudi pozneje in ga vedno znova opredeljuje, vendar je najbolj prepričljiv ravno ta prvotni opis pojava nespečnosti, v kateri otrok doživlja neke vrste tišino v ozadju vsega (EE: 109).

To izkustvo je postalo izhodišče za globlji filozofski uvid. V pojavu nespečnosti v temi, ki je povezana $\mathrm{z}$ grozo in obenem $\mathrm{z}$ občutkom, da ni izhoda iz temnega bivanja, $v$ katerem subjekt še ni prešel v zavest o sebi (Levinas to stopnjo imenuje hipostaza), je zaobsežena vsa praznina neskončnega prostora, v katerem si sam s svojim strahom, prepuščen lastnemu obstoju, ne da bi poznal razlog zanj.

20 Levinas, De l'existence à l'existant, 98-105. 
To občutje, ki spominja na eksistencialiste, vodi Levinasa v iskanje "pobega« iz individualnosti, ki bi bila nemočno prepuščena usodi ali iz katere bi ga lahko izpeljala le »težavna svoboda« $\mathrm{z}$ odločitvami, ki bi šele oblikovale subjektivnost. Levinasova pot iz neopredeljivega, a brezizhodnega il y a je paradoksalna, kajti vodi v tiste vrste pasivnost, ki je najvišja stopnja dejanja. ${ }^{21}$ Človek postaja subjekt - a ne $z$ dejanjem, ki bi izhajalo iz njegove aktivnosti, kajti za Levinasa najčistejšo in edino pristno človeško dejavnost lahko pomeni le dejanje, ki je odgovor na klic, na obličje sočloveka. V tej poklicanosti pomeni pasivnost tisto odprtost, ki je potrebna, da subjekt stopa iz svoje samosti in samozadostnosti v območje Drugega, ki je neskončna Drugost. Obenem je ta stopnja pasivnosti odprtost do Neskončnosti, ki se pojavlja kot poziv k neskončni etični odgovornosti do Obličja sočloveka. Morda tako visoke etične zahteve presegajo omejene zmogljivosti končnega bitja, kot je človek. A Levinas pojmuje človeka kot sled Neskončnosti, torej se ta "pojavlja« kot klic in kot odgovor na ravni presežnosti, na ravni preseganja končnosti. Toda neskončnosti ne postavlja »onkraj«, kajti ta »onkraj«, ki mu je sicer blizu že v Platonovi ideji Dobrega, je uresničevanje "po-klica« človeka. Ta po Levinasu obstaja le kot od-govor.

Pojmovanje neskončnosti in odnosa med Anaksimandrovim ắcıрov ter Levinasovim il y a je tema, ki jo v svoji razpravi ${ }^{22}$ obravnava denimo Danne Polke. Med drugim omenja vpliv Husserlove fenomenološke metode ${ }^{23}$ na Levinasa. Gre za izviren izraz zanimanja sodobne misli za prvinska "predsokratska« vprašanja o počelu, o naravi in o vračanju $\mathrm{k}$ »arheologiji« človeka v smislu etične zavesti, tudi v odnosu do narave, kar pa spada že med aplikacije Levinasove misli na različna področja, v tem primeru na ekologijo; tudi prepoznavanje Obličja narave kliče k od-govornosti.

\section{ANAKSIMEN}

Nenavadno je dejstvo, da med omembami predsokratikov v Levinasovem korpusu ne zasledimo Anaksimena. Obenem pa v literaturi lahko najdemo tezo, da je prav Anaksimen izmed vseh predsokratikov najbližji Levinasu, zlasti njegovemu pojmovanju "psihizma«. Silvia Benso ${ }^{24}$ obravnava dihanje kot izraz oživljajočega principa 
življenja, vendar ne v najožjem biološkem smislu. Jonski naravoslovci izhajajo iz narave. Narava je elementarna, brezosebna. Vprašanje pa je, kako si lahko razlagamo pojme, ki bi lahko pomenili razširitev tega koncepta. Narava bi bila $v$ nekem smislu duhovna in prisotna v zraku in dihanju, ki oživlja dušo. Gre za razumevanje duševnosti kot pred-enovitosti telesnega in duševnega pred poznejšim dualizmom, ki je zaznamoval zahodno misel. Ta enoviti pred-obstoj naj bi obsegal dihanje kot telesno dejavnost človeka od rojstva do smrti in duševnost kot oživljajočo psihično dejavnost. Kot piše Silvia Benso, velja Anaksimen za prvega v zgodovini filozofije, ki je spregovoril o duhu. Ta jonski mislec je duh povezoval z zrakom, $\mathrm{z}$ dihanjem in $\mathrm{z}$ dušo. (Pozneje so misel razvili stoiki.) Takole pravi Anaksimen: »Kakor naša duša, ki je zrak, obvladuje nas, tako tudi dih in zrak zaobsegata celoten svet. ${ }^{25}$

Gre torej za vzporejanje zraka (åń $\rho$ ) kot materialnega in duha $(\pi v \varepsilon \tilde{v} \mu \alpha)$ kot nematerialnega, oboje pa daje življenje duši ( $\psi v \chi \eta ́)$. Vdih in izdih ponazarjata povezavo med zunanjim in notranjim.

Ko Levinas govori o "psihizmu«, gre za danost, ki obstaja pred cepitvijo na telesno in duševno, kakor pri Anaksimenu. Človeka prežema prvobitna nedolžnost in harmonija predsokratske elementarne narave. Pri Levinasu najde sicer izraz v fenomenološkem jeziku, vendar gre za prvinsko izkustvo veselja do življenja v občutju, čutenju, doživljanju. »Psihizem ${ }^{26}$ pa je šele pred-stopnja soočenja $z$ odgovornostjo. Etična drža je po Levinasu vedno »utelešenje«, etični odgovor je gostoljubje, je odgovor na lakoto, žejo, prezeblost sočloveka. V tem smislu bi bil lahko duh, $\pi v \varepsilon \tilde{v} \mu \alpha$, tisti, ki vstopa kot višja zavest psihičnega v "psihizem《 doživljajskega sveta, $\pi v \varepsilon \tilde{u} \mu \alpha$, ki je obenem dih življenja in prehajanje med telesnim in duševnim, kar pa je po svoje skupno Anaksimenu in Levinasu. Tako Silvia Benso razume vzporednice med Anaksimenom in Levinasom.

Interpretacija Levinasa v luči Anaksimena je seveda mikavna, toda zdi se, da avtorica ne upošteva Levinasovega fenomenološkega obzorja na podlagi Husserlovih spisov. Levinasu duša (âme) in psihizem že pomenita animirano ali oživljeno telesnost, ki se do drugega že obnaša odgovorno. »Psihizem« ni šele "predstopnja» odgovornosti, ampak je že odgovornost. Kajti po Levinasu sem odgovoren, še preden se tega zavem. 
Dejstvo je, da ravno fragmentarnost predsokratikov dopušča različne razlage in da je tako pri Levinasu bolj kot iskanje »vpliva« v njegovem dialogu s predsokratiki primerneje razbirati njihove uvide kot vir navdiha za lastno poglabljanje v pra-korenine biti.

\section{HERAKLIT}

Pomemben vir navdiha je za Levinasa tudi Heraklit. Tu je še Parmenid, ki pa je predvsem avtoriteta, do katere je Levinas kritičen, saj mu pripisuje monizem, ki poenoti mnoštvo v eno. To pa po Levinasu pomeni zametek poznejše zahodne »totalitete« v filozofski misli.

$\mathrm{V}$ poglavju z naslovom »Infini« iz že omenjenega izbora Levinasovih razprav, objavljenih v AT, ${ }^{27}$ se takole spomni Empedokla v povezavi s Heraklitom ${ }^{28}$ in drugimi misleci te dobe:

Od Heraklita do Empedokla, vse do poslednjih stoikov se bo uveljavljala ideja o kozmičnem ponavljanju, da si svetovi sledijo v neprekinjenem času. (AT 75:29)

V svetovih, ki se ciklično ponavljajo, ni napredka; pač pa Levinas v nadaljnjih vrsticah omenja atomiste, pri katerih idejo periodičnega vračanja nadomesti ideja neskončnega zaporedja časa, ki prinaša vedno nekaj novega, kot piše na istem mestu v AT.

Heraklitov fragment $» v$ iste reke stopamo in ne stopamo, smo in nismo $«{ }^{29}$ je imel velik odmev, k Heraklitu se Levinas vrača v številnih omembah. Naveže se na različico v Platonovem dialogu Kratil, ki ga navajajo Fragmenti: »Heraklit nekje pravi, da `se vse premika in nič ne ostaja‘, in ko bivajoče stvari prispodablja toku reke, pravi, da ne moreš dvakrat stopiti v isto reko. ${ }^{30}$ Levinas doda, da mu je še bliže Kratilovo stališče, da v isto reko ne moremo stopiti niti enkrat samkrat, kaj šele dvakrat. Gre za odlomek iz Levinasovega dela Le Temps et l'Autre (TA):

Levinas, Altérité et transcendance, 75.

Poleg jonskih filozofov najdemo pri Levinasu še omembe Pitagore (THI 35:31) in starejših pitagorejcev, med katerimi je po številu omemb opazen predvsem Heraklit. Levinas ga omenja v več delih: TA 28:17; TI 9:15; 31:5; 31:14; NP 41:11, 171:9; DMT 86:12, 90:24, 282:2; IH 29:15; HS 115:30; AT 75:29.

Diels in Kranz, Fragmenti predsokratikov, 385 (fragment 22 B 49a DK). Ibid., 361 (fragment 22 A6 DK). 


\begin{abstract}
Če pa bi moral primerjati pojem »obstaja« $[i l y a]$ s kakšno veliko temo klasične filozofije, bi pomislil na Heraklita. Ne na zgodbo o reki, v kateri se ne moremo kopati dvakrat, temveč na Kratilovo različico, na zgodbo o reki, v kateri se ne moremo kopati niti enkrat; v kateri se ne more vzpostaviti niti stalnost enotnosti, oblike vsakega obstoječega; o reki, v kateri je izginila poslednja prvina stalnosti, glede na katero razumemo postajanje. (TA 28:17)
\end{abstract}

Podobno omembo s komentarjem najdemo v Levinasovem temeljnem delu Totalité et infini. ${ }^{31} \mathrm{~V}$ naslednjem odlomku gre za nasprotujoči si stališči Heraklita in Parmenida. Levinas je v tem smislu "na strani« Heraklita, saj mu njegovo pojmovanje sveta kot »trajno« spremenljivega dopušča več "prostora« za njegovo »drugost«, $s$ katero želi Levinas preseči parmenidovski monizem, poenotenost mnoštva, ki daje prednost istosti pred drugostjo. Levinas pravi takole:

Nastajanje tako prevzema le vrednost neke ideje, ki je radikalno nasprotna ideji biti, predstavlja odpor do vsake vključitve, ki jo posreduje podoba reke, ali - po Heraklitu - v isti reki se ne kopamo dvakrat (v isto reko stopamo in ne stopamo), po Kratilu pa niti enkrat samkrat. Pojem nastajanja, ki razkraja Parmenidov monizem, se ne uresničuje drugače kakor prek posamičnosti čutenja. (TI 31:14)

To razlago dopolnjuje Levinas $\mathrm{v}$ drugem, temu podobnem odlomku, kjer pa izhaja iz Platonovega dialoga Teajtet 2, v katerem nastopa tudi Protagora:

Ni naključje, da se v Teajtetu Protagorova trditev približuje Heraklitovi, kot da bi bila potrebna posamičnost čutenja, da bi se Parmenidova bit lahko razpršila v nastajanju in se odvijala drugače kot objektivni tok stvari. (TI 31:5)

Med temeljnimi Heraklitovimi trditvami v fragmentih pa Levinas omenja tudi misel o nasprotju, o boju, ki kot neizbežen princip deluje v vsem, kar obstaja. V Fragmentih beremo Heraklitovo stališče: "Treba je vedeti, da je boj obči in da je pravica spor in da vse obstaja po sporu in potrebi. ${ }^{32}$ 
To misel Levinas potrjuje in zaostri s komentarjem, da nam tega več kot očitnega dejstva ni treba iskati pri »mračnem Heraklitu«, saj je spoznanje o nasprotju kot principu stvarnosti splošno človeško izkustvo. Kako gleda Levinas na ta Heraklitov uvid, je razvidno iz naslednjega odlomka, spet iz Totalité et infini:

V filozofski misli dokazov, da se bivanje razodeva kot boj, ni treba iskati v mračnih Heraklitovih fragmentih; boj ne zadeva bivanja le kot najočitnejše dejstvo, temveč kot očitnost samo - kot resnico realnega. (TI 9:15)

Podobno misel najdemo v drugem odlomku, v izboru Levinasovih besedil Les imprévus de l'histoire, ki segajo od leta 1929 do 1992, in sicer v razmišljanju o hitlerizmu kot travmi skrajnega primera totalitete. ${ }^{33}$ Gre za poglavje, ki je v nekem smislu postalo najgloblji smoter vseh Levinasovih miselnih naporov. Totaliteta ni le filozofski pojav, vendar je Levinas prepričan, da jo je mogoče izkoreniniti ravno $\mathrm{z}$ »ljubeznijo do modrosti«, v iskanju »pra-počela«, izhodišča torej, ki se mu človek ne more izmakniti. Gre za upoštevanje drugega, sočloveka kot nepreklicni etični od-govor. Takole pravi:

Za otožnostjo večnega pretakanja stvari, iluzorne Heraklitove sedanjosti, je tragedija nepremičnosti neke neizbrisne preteklosti, ki obsodi pobudo, da ta ni nič drugega kot le neko nadaljevanje. (IH 29:15)

Ozadje Levinasove misli tako ni le zgodovina, ampak tudi njegova izkušnja, ki je v njegovih delih »prevedena« v filozofski diskurz.

\section{PARMENID}

Izstop iz totalitete in radikalna kritičnost do zgodovine filozofije se pri Levinasu začenja v odnosu do Parmenida. Po številu omemb je ta med predsokratiki v Levinasovih delih daleč na prvem mestu. ${ }^{34}$

34 THI 127:2O; DE 96:16; TA 20:22, 22:23, 78:4; TI 21:6, 21:40, 31:6, 31:16, 36:20, 75:22, 76:17, 77:38, 78:10, 247:11; EDE 54:17, 74:43, 100:5, 10O:11, 121:12, 155:37, 189:40, 197:15; HAH 36:11, 57:13, 94:27; AE 36:38, 69:25, 138:9, 138:31, 140:35, 211:10; NP 29:5, 31:20, 39:13, 39:21, 75:35, 156:4, 190:12; DMT 90:17, 90:20, 282:36; IH 136:3; ADV 155:10; DQVI 71:9, 267:2; HS 103:7, 104:26; HN 210:35, 211:10; AT 30:1, 76:5. Le del omemb se nanaša na filozofa, preostale obravnavajo Platonov istoimenski dialog. 
Med pomembnejše odlomke spadajo tisti, v katerih se Levinas izrecno odloča za odmik od Parmenidovega pojmovanja resničnosti: bit je, ne biti ni, mnoštvo vsega bivajočega je videz, edina resničnost je bit, ki je ena sama. ${ }^{35}$

Da, jaz bom govorila, ti pa besedo sprejmi, ko jo slišiš,

katere (mogoče) umeti je poti iskanja.

Prva je, da je, da ni ne biti;

to je steza prepričanja, saj sledi resnici.

Druga pa je, da ni in da mora ne biti.

O tej poti ti pokažem, da ni o njej mogoče izvedeti prav nič. ${ }^{36}$

Na zgornji odlomek in nasploh na Parmenida se Levinas odziva predvsem kritično:

In brez pridržka smo primorani proti Parmenidu izjaviti, da ne-biti je. (DE 96:16, 121:32)

V svojem delu Čas in drugi (TA) Levinas govori o Parmenidu v povezavi s Heglom, predvsem ob vprašanju mnoštva in enotnosti. Prisoja mu vlogo »očeta enotnosti biti«. Levinas ne išče enotnosti in še manj heglovske dialektike, ki bi vso drugost želela zvesti na istost istosti in neistosti - navidezno antitetičnega mišljenja, ki pa vse razlike oziroma negacije poenoti v neko »višjo« sintezo. Levinasova pot je drugačna, je v tem smislu »prekinitev« s Parmenidom.

Naslednji odlomek spada v prvo poglavje TA s podnaslovom "Predmet in načrt", drugi pa v naslednje poglavje TA, "Samota obstajanja«. Levinas uvodoma opozarja, da ta predavanja ne bodo govorila o osamljenosti subjekta v času, temveč o času kot »odnosu subjekta z bližnjim«.

To, kar ta izvajanja morebiti vsebujejo dialektičnega, vsekakor ni heglovsko. Ne gre za to, da bi prečkali serijo protislovij, niti da bi jih (med seboj) spravili, ko bi zaustavili zgodovino. Nasprotno, odpraviti se hočem proti pluralizmu, ki se ne zliva $\mathrm{v}$ enost; hočem, če si je moč to drzniti, prelomiti s Parmenidom. (TA:20:22)

36 Diels in Kranz, Fragmenti predsokratikov, 529 (fragmenti 28 B 2 DK); več o Parmenidu 494-553. 
Zapustiti Parmenida pomeni za Levinasa »zlati rez«, ki se ob popolni ločenosti na novo začenja zavedati neizbežnega izvornega mnoštva. Ta zavest je pogoj za ohranjanje brezpogojne »drugosti drugega«.

Pristopiti k obstajanju v obstoječem pomeni obstoječe zapreti v edinost in pustiti Parmenida, da se izogne vsakemu očetomoru, ki bi ga bili nad njim skušali izvršiti njegovi potomci. (TA 22:23)

V gornjem odlomku je Levinas uporabil skrajno metaforo očetomora, ki spominja na grško tragedijo.

Na več mestih, tudi v izboru razprav AT, zasledimo izjavo, da je Platon prvi, ki se je odrekel Parmenidovi viziji sveta in jo povsem preoblikoval:

Platon bo zagrešil očetomor s trditvijo, s katero nasprotuje svojemu očetu Parmenidu, da ne-biti v nekem smislu je. (AT 76:5)

K tej metafori o očetomoru se večkrat vrača, da bi nazorno prikazal, kako se izrecno odreka edinosti biti. Ta »mnoštvenost « kot njeno nasprotje pa ni sociološka ali antropološka, ampak ima globlje ontološke korenine, zasidrana je v obstoj človeka od rojstva do smrti. Toda ravno ta "samota « je po Levinasu presežena v izvorni etičnosti »biti za drugega«, ki je pred »prebuditvijo subjekta«že bila zapisana vanj.

Iskanje drugosti, ki ni zvedljiva na istost, je po Levinasu poleg družbenosti nedvomno eros oziroma ženskost in moškost. Ravno ženskost je zanj prototip drugosti. To je pozneje razvil v fenomenološko dojemljiv izraz »Obličje «. ${ }^{37}$ Trditev, ki jo poglobi v drugih delih, npr. v TI, zapiše v strnjeni obliki v drugem poglavju dela Čas in drugi:

Razlika spolov je sicer formalna struktura, ki pa vendarle razceplja stvarnost $\mathrm{v}$ drugem smislu in pogojuje možnost stvarnosti kot mnogotere, v nasprotju $\mathrm{z}$ edinostjo biti, ki jo je oznanil Parmenid. (TA 78:4)

V navedenem odlomku iz TA in v sledečih iz TI, v katerih Levinas prav tako omenja Parmenida, so nakazani trije tematski krogi, okrog katerih se razvija Levinasova misel in ki se med sabo dopol- 
njujejo. ${ }^{38}$ To so eros, ${ }^{39}$ družbenost $^{40}$ in - predvsem zaradi nenehnih literarnih reminiscenc in pogostih slogovno zaznamovanih izrazov - umetnost $\mathrm{v}$ najširšem pomenu besede. ${ }^{41}$ Pri tem gre tako za pogosta razmišljanja o jeziku, o izrekanju in izrečenem, pa tudi za pesniško izražanje Levinasa samega, ki izrecno omenja antične mite in znana imena iz evropske literarne zakladnice, da bi metaforično izrazil neizrekljivo. Ali ni - kljub vsej kritičnosti do umetnosti - $s$ tem Levinas sam zašel tudi $v$ ta tematski $k r o g,{ }^{42} \mathrm{ki} \mathrm{sam} \mathrm{po} \mathrm{sebi} \mathrm{ne}$ bi spadal v filozofski diskurz? Sporočilo vseh Levinasovih izvajanj se giblje okrog »osi« meta-etike, ki je po njegovem obenem nosilna os človeštva.

Predpogoj metaetike pa je izvorna mnoštvenost, ki prekinja z monizmom. Ta namreč vodi v mišljenje "totalitete«, ki jo Levinas odklanja. V svojem temeljnem delu Totalité et infini (TI) na več mestih omenja Parmenida, ob njem pa svoj odmik od njega v dialogu $\mathrm{z}$ drugimi misleci:

Istost in Drugost ohranjata odnos, obenem pa se odvezujeta od tega odnosa, tako da ostajata absolutno ločena. Ideja Neskončnosti zahteva to ločenost. Ta je bila postavljena kot poslednja struktura bitja, kot učinek njegove lastne neskončnosti. Družba jo izpolnjuje konkretno. Toda pristopati k bitju na ravni ločenosti, ali to ne pomeni pristopati k njegovemu propadu? Stališča, ki jih bomo povzeli, nasprotujejo antični enosti, ki velja od Parmenida do Spinoze in Hegla. (ті 36:20)

V nadaljevanju istega dela je pri Levinasu več daljših predstavitev antitetičnega mišljenja ${ }^{43} \mathrm{v}$ odnosu do filozofskih poudarkov, ki jih imenuje »parmenidovski«:

Bitje nastaja kot mnogotero. In kot razpeto med Istost in Drugost. To je temeljna struktura. Bitje je družbenost in s tem čas. ${ }^{44}$ Tako izstopamo iz parmenidovske filozofije biti. Filozofija sama pomeni trenutek tega izpolnjevanja časa, pogovora, ki se vedno obrača na nekoga drugega. (тI 247:11)

38 Staehler, Plato and Levinas.

39 Ibid., 79-9o.

40 Chalier, Levinas, l'utopie de l'humain, 109-31.

41 Staehler, "The Refuge of the Good in the Beautiful«, 1-20.

42 Levinas, RO, 123-54.

43 Levinas, EN, 201-16. Gre za eno izmed razprav o kulturi, vendar Levinasov antitetični način razmišljanja izstopa še na nešteto drugih mestih.

44 Totalité et infini, 187-201. 
Zgoščeno stališče o različnih kulturah pa najdemo v Levinasovem delu Humanisme de l'autre homme (Humanizem drugega človeka). In sicer:

Pravijo nam seveda, da se kulturni pomeni ne izneverijo biti zaradi svoje mnoštvenosti, temveč se prek tega le dvignejo $\mathrm{k}$ meri in $\mathrm{k}$ bistvu biti, to je k njenemu načinu biti. Bit ne obstaja na način, da bi omrtvela v parmenidovski sferi, identična s seboj, niti v ustvarjenem bitju, ki je zaključeno in nepremično. (HAH 36:11)

Pri Levinasu je odnos, to je odprtost do drugega, zapisan v samo strukturo človeka. ${ }^{45}$ Iz tega izhaja, da ni ničesar, kar bi bilo pomembnejše, bolj resnično, bolj obvezujoče, »starejše«, bolj izvorno in bolj »logično« ( $\lambda$ ójoৎ v pomenu »smisla«), kakor je ta človeška danost. $\mathrm{V}$ delu z naslovom Noms propres, kjer obravnava različne sodobnejše mislece in književnike, je tudi nekaj pomenljivih izjav ob dialogu s Parmenidom:

Odnos Jaz-Ti je odnos z nekom, ki ostaja absoluten kljub odnosu. Parmenidov problem resnice je rešen v socialnem odnosu kot medčloveški odnos. (NP 39:21)

Razmišljanje o Marcelu Proustu ${ }^{46}$ prav tako izpostavlja odnos do Parmenida:

Paradoksalno pojmovanje civilizacije, ki kljub razvoju, ki se je odvijal od eleatov dalje, vidi v enotnosti celo apoteozo bitja. Toda najgloblje Proustovo sporočilo [...] je v postavljanju realnega v odnos z nekom, ki za vedno ostaja drugi (autre), z drugim (autrui) kot odsotnostjo in skrivnostjo, da bi jo našel v intimnosti samega »Jaza«, da bi vpeljal neko dialektiko, ki dokončno prekine s Parmenidom. (NP 156:4)

S tem odlomkom se vračamo $\mathrm{k}$ izhodiščnemu vprašanju. $\mathrm{V}$ čem je Levinasova globoka povezanost s predsokratiki? ${ }^{47}$ Nedvomno so zanj vir navdiha, ne glede na to, ali gre za izhajanje iz njihove arhaične misli o prapočelu ali za odmik od njih v smeri lastne izvirne miselne poti. Ta namreč nikoli ne zanika uvidov svojih predhodnikov, ampak se obrača $\mathrm{k}$ njim $\mathrm{z}$ odprtostjo iskalca resnice in s tem grške 
»ljubezni do modrosti«. Levinas predsokratike obravnava spoštljivo, kot bi v njih odkrival arhaičnost, ki jo na svoj način išče tudi sam. Zelo očitno pa je med njimi Parmenid mislec, ki ga najbolj zaposluje in s katerim se najpogosteje sooča.

Levinas je pri predsokratikih iskal svoje predhodnike, vendar jih je našel le do neke mere. Sam je želel iti dlje od njihove ả $\rho \eta \underline{~ i n ~}$ iskati to, kar je pred počelom, ki daje misliti. Levinas je iskal rojevanje tega počela, zato je kasneje iznašel izraz an-arché, ${ }^{48}$ razmišljal je o an-arhičnosti. ${ }^{49} \mathrm{Za} \mathrm{Levinasa^{50 }}$ počelo še ni začetek misli, išče tisto, kar je pred njim, kar ga rojeva. Zato je tudi v svojem znamenitem uvodu v Rosenzweigovo ${ }^{51}$ delo Zvezda odrešenja očital jonskim filozofom, se pravi predsokratikom, da iščejo samo eno počelo in da hočejo z njim razložiti prav vse. Prav to je očital tudi Heglovemu pojmovanju, ki sicer vključuje drugost (altérité), pa je vendar vseobsegajoč in zaradi tega totalitaren.

Vsekakor pa Levinas predsokratikom priznava vrednost, ker so iskali izvor stvarstva in človeške misli ter hkrati princip doslednega mišljenja, brez katerega ni filozofije. Sam bo to doslednost našel v etični zahtevi do sočloveka. Prednost te skrajne etične zahtevnosti pa bo v tem, da ne bo vsega izpeljala na eno samo počelo ali princip. Namesto tega bo mislila drugost tako, da bo drugost, konkretni drugi človek, ostala drugost in nikoli ne bo použita v eno.

\section{BIBLIOGRAFIJA}

\section{Kratice Levinasovih del}

ADv L'au-delà du verset: Lectures et discours talmudiques. Pariz: Éditions de Minuit, 1982.

AE Autrement qu'être ou au-delà de l'essence. La Haye: Martinus Nijhoff, 1974.

AT Altérité et transcendance. Montpellier: Fata Morgana, 1989. Ponatis 1995.

DE De l'évasion. Montpellier: Fata Morgana, 1935. Ponatis 1982.

DL Difficile liberté: Essais sur le judaïsme. Pariz: Albin Michel, 1976. Slovenski prevod Jasmina Rihar, Težavna svoboda. Celje: Celjska Mohorjeva družba, 2012.

49 Klun, Das Gute vor dem Sein, 222-24.

50 Levinas, À l'heure des nations, 175-85.

51 Rosenzweig, Der Stern der Erlosung. 
DMT Dieu, la mort et le temps. Pariz: Grasset, 1976.

DQVI De Dieu qui vient à l'idée. Pariz: Vrin, 1982.

EDE En découvrant l'existence avec Husserl et Heidegger. Pariz: Vrin, 1967.

EE De l'existence à l'existant. Pariz: Vrin, 1947. Ponatis 1993.

EI Éthique et infini: Dialogues avec Philippe Nemo. Pariz: Fayard, 1982. Slovenski prevod Edvard Kovač, Etika in neskončno. Ljubljana: Družina, 1998.

EN Entre nous: Essais sur le penser-à-l'autre. Pariz: Grasset, 1991.

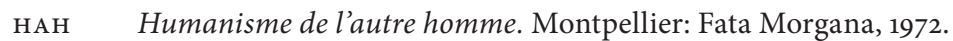

HN À l'heure des nations. Pariz: Editions de Minuit, 1998.

HS Hors sujet. Montpellier: Fata Morgana, 1987.

IH Les imprévus de l'histoire. Montpellier: Fata Morgana, 1994.

NP Noms propres. Montpellier: Fata Morgana, 1976.

QR $\quad$ Quelques réfexions sur la philosophie de l'hitlérisme«. V: Les imprévus de l'histoire, ur. Pierre Hayat (Montpellier: Fata Morgana, 1994), 27-41; ponatis iz revije Esprit 26 (1934). Slovenski prevod Miklavž Ocepek, »Nekaj razmišljanj o filozofiji hitlerizma«, Apokalipsa 6-7 (1995), 13-21.

RO $\quad$ Ra réalité et son ombre«. Les Temps Modernes 4, št. 38 (1948). Ponatis v zborniku Levinasovih razprav Les imprévus de l'histoire (Montpellier: Fata Morgana, 1980; ponatis 1994).

TA Le temps et l'autre. Pariz: Quadrige, 1947. Ponatis 1994. Slovenski prevod Gorazd Kocijančič, Čas in drugi. Ljubljana: Družina, 1989.

TEI Transcendance et intelligibilité. Ženeva: Labor et fides, 1983. Ponatis 1996.

THI Théorie de l'intuition dans la phénoménologie de Husserl. Pariz: Vrin, 1930. Ponatis 1970.

TI Totalité et Infini: Essai sur l'extériorité. La Haye: Martinus Nijhoff, 1961.

\section{Sekundarna literatura}

Bauman, Zygmunt. Postmodern Ethics - Postmoderna etika. Prevod Urban Tarman. Ljubljana: Znanstvena založba Filozofske fakultete, 2016.

Benso, Silvia. »The Breathing of the Air: Presocratic Echoes in Levinas«. V: Levinas and the Ancients, ur. Brian Schroeder in Silvia Benso, 9-24. Bloomington: Indiana University Press, 2008.

Chalier, Catherine. Levinas, l'utopie de l'humain. Pariz: Albin Michel, 1993. Dastur, Françoise. „Levinas and Heidegger: Ethics or Onthology? « V: Between Levinas and Heidegger, ur. John E. Drabinski in Eric S. Nelson, 133158. New York: suny Press, 2014. 
Diels, Hermann in Walther Kranz. Fragmenti predsokratikov. Prevod Daša Benko, et al., ur. Gorazd Kocijančič. Vol. 1-3. Ljubljana: Študentska založba, 2012.

Klun, Branko. Das Gute vor dem Sein - Levinas versus Heidegger. Frankfurt na Majni: Peter Lang, 2000.

___. »L'infini et la passivité: Le 'tournant' de la pensée de Levinas après Totalité et infini«. V: Emmanuel Levinas et la pensée de l'infini, ur. Monique Cohen. Toulouse: Les Presses Universitaires de l'ICT, 2016.

Kocijančič, Gorazd. »Drugi čas? Drugačen drugi?« V: Le temps et l'autre Čas in drugi, ur. Matija Ogrin. Ljubljana: Družina, 1998.

Marinčič, Marko. Grška književnost arhaične dobe: zgodovinski, problemski in bibliografski uvod. Ljubljana: Filozofska fakulteta Univerze v Ljubljani, Oddelek za klasično filologijo, 2004.

Marion, Jean-Luc. L'idole et la distance. Pariz: Grasset, 1977. Slovenski prevod Malik in razdalja. Prevod Barbara Pogačnik in Maja Novak. Ljubljana: KUD Apokalipsa, 2010.

Narbonne, Jean-Marc. Levinas et l'héritage grec. Pariz: Librerie Philosophique J. Vrin, 2004.

Petrosino, Silvano in Jacques Rolland. La vérité nomade: Introduction à Emmanuel Lévinas. Pariz: La Decouverte, 1984.

Polke, Danne. »Good Infinity/Bad Infinity: Il y a, Apeiron, and Environmental Ethics in the Philosophy of Levinas«. Philosophy in the Contemporary World 7, št. 1 (200o): 35-40.

Rosenzweig, Franz. Der Stern der Erlosung. Frankfurt na Majni: Suhrkamp, 1988.

Schroeder, Brian in Silvia Benso, ur. Levinas and the Ancients. Bloomington: Indiana University Press, 2008.

Staehler, Tanja. Plato and Levinas: The Ambiguous Out-Side of Ethics. London: Routledge, 2010.

—_ - »The Refuge of the Good in the Beautiful«. Epoche: A Journal of the History of Philosophy 20, št. 1 (2015): 1-20. 


\section{IZVLEČEK}

Levinasovo vrednotenje predsokratikov (Tales, Anaksimander, Anaksimen, Heraklit, Parmenid) na obzorju grškega logosa izhaja iz

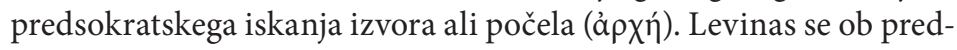
sokratikih navdihuje za izvirno pojmovanje neke pred-časovnosti, ki jo poimenuje an-arché. Iz nje izpelje mnoštvenost (pluralnost), ki zanj izhaja iz te izvorne drugosti. Pri Anaksimandru in njegovem

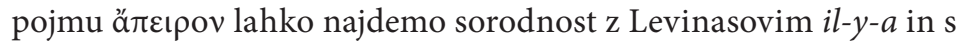
pojmom neskončnosti, pri Anaksimenu sorodnost z Levinasovim pojmovanjem psihizma, pri Heraklitu pa z dinamiko spreminjanja, ki odpira prostor drugosti. Najpogosteje se Levinas zaustavlja pri Parmenidu, saj ob njem razvija kritičnost do njegovega monizma. Levinasu gre za iskanje izvorne Drugosti drugega, v kateri se po njegovem izraža neskončna etična odgovornost.

KLJUČNE BESEDE: Emmanuel Levinas, predsokratiki, počelo

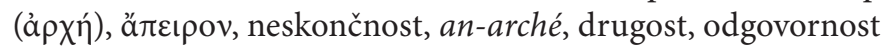




\section{ABSTRACT}

Levinas' evaluation of the pre-Socratics (Tales, Anaximander, Anaximenes, Heraclitus, Parmenides) on the horizon of the Greek logos begins with the pre-Socratic search for the origin or the first principle (å $\rho \chi \eta ́)$. The pre-Socratics are the stimulus behind his original conception of a pre-temporality, which he calls an-arché. This pre-temporality is his source for plurality, derived from the original otherness. Anaximander and his concept of äreııov provide the background for the Levinasian $i l-y-a$ and the notion of infinity; Anaximenes is related to the conception of psychisme; Heraclitus corresponds to the dynamic of change that opens up the space of Otherness. Most often, however, Levinas engages with Parmenides, developing a critique of his monism, based on his search for the original Otherness of the Other, in which infinite ethical responsibility is expressed.

KEYWORDS: Emmanuel Levinas, pre-Socratics, first principle

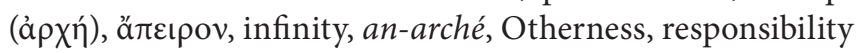

